УДК 336

DOI: https://doi.org/10.26642/jen-2020-4(94)-88-98

\author{
Ю.С. Костишин, аспірант \\ Державний університет «Житомирська політехніка»
}

\title{
Науково-методичний підхід до оцінювання ефективності митного контролю в системі фінансової безпеки
}

\author{
(Представлено: д.е.н., проф. Петрук О.М.)
}

\begin{abstract}
Статтю присвячено дослідженню функиіонування блоку оичіни результатів митного контролю, що вимагає розробки методичного забезпечення такої оцінки та формування показників і критерї̈в результативності й ефективності контрольної діяльності. Визначено, щчо сьогодні не існує єдиної методики оцінки ефективності митного контролю. Це обумовлено такими причинами: по-перше, митний контроль має власну специфіку оцінки, щзо вимагає формування відповідних показників та критерії; по-друге, триває дискусія з приводу придатності для цุілей очінки ефективності часткових або все ж таки інтегральних показників; по-третє, $\epsilon$ плутанина з приводу оцінки результативності, дієвості та ефективності контролю як близьких за змістом оціночних характеристик. Відсутність єдиної методики оцінки ефективності митного контролю в системі фінансової безпеки, важливість розробки оціночних показників та критеріїв для таких иілей свідчить про актуальність та значущість теми дослідження в иььому напрямі. Метою статті є аналіз наукових підходів до ефективності контрольної діяльності та розробка методичного забезпечення оцінки ефективності митного контролю в системі фінансової безпеки. Очінка переваг та недоліків існуючих методичних підходів до аналізу ефективності митного контролю надала можливість обрати науковометодичний підхід, який є поєднанням підходу, орієнтованого на бенчмаркінг результатів із застосуванням методу Евклідової відстані, $і$ клієнтоорієнтованого підходу, результатом використання якого $є$ визначення інтегрального показника ефективності діяльності регіональних митниць та ідентифікація місия кожної митниці в одержаному кінцевому рейтингу шляхом проведеного ранжування з використанням методики «суми місць». Прикладне застосування запропонованого науково-методичного підходу дозволить визначити ефективність діяльності митних органів з позииії збільшення митних надходжень до бюджету та забезпечення відповідного рівня фінансової безпеки, встановити ступінь задоволеності користувачів митних послуг діяльністю митних органів.
\end{abstract}

Ключові слова: митний контроль; ефективність контролю; ефект контролю; оцінка ефективності.

Постановка проблеми у загальному вигляді та її зв'язок 3 важливими практичними завданнями. Одним 3 елементів механізму митного контролю $є$ блок оцінки, що призначений для аналізу результатів здійсненого контролю та оцінювання дотримання нормативних індикаторів системи фінансової безпеки. За недотримання рівня зазначених показників фінансової безпеки приймається управлінське рішення, спрямоване на підвищення рівня ефективності механізму для подальшого зменшення або усунення виявлених відхилень. Функціонування блоку оцінки результатів митного контролю вимагає розробки методичного забезпечення такої оцінки та формування показників та критеріїв результативності та ефективності контрольної діяльності.

Аналіз останніх досліджень та публікацій. Питанню формування методик оцінки ефективності контролю присвячували свої праці вітчизняні та закордонні вчені: С.В. Бардаш, Н.Г. Виговська, Л.В. Гуцаленко, В.А. Дерій, І.К. Дрозд, Н.В. Шевченко, О.А. Шевчук, В.О. Шевчук та інші. Водночас єдиної методики оцінки ефективності митного контролю до цього часу не існує. По-перше, митний контроль має власну специфіку оцінки, що вимагає формування відповідних показників та критеріїв. Подруге, триває дискусія з приводу придатності для цілей оцінки ефективності часткових або все ж таки інтегральних показників. По-третє, є плутанина 3 приводу оцінки результативності, дієвості та ефективності контролю як близьких за змістом оціночних характеристик. Відсутність єдиної методики оцінки ефективності митного контролю в системі фінансової безпеки, важливість розробки оціночних показників та критеріїв для таких цілей свідчить про актуальність та значущість теми дослідження в цьому напрямі.

Метою статті $\epsilon$ аналіз наукових підходів до ефективності контрольної діяльності та розробка методичного забезпечення оцінки ефективності митного контролю в системі фінансової безпеки.

Викладення основного матеріалу. Під час дослідження питань ефективності митного контролю слід розрізняти споріднені, близькі за змістом поняття та категорії (результативність, дієвість, ефект).

(C) Ю.С. Костишин, 2020 
Етимологічне значення слова «результативність» у тлумачних словниках визначається у декількох розрізах: 1) як остаточний, кінцевий підсумок якого-небудь заняття, діяльності, розвитку тощо; 2) як наслідок якої-небудь дії, якогось явища тощо; 3) як показник чого-небудь [10]. У контексті контролю результативність слід розуміти як результат функціонування системи митного контролю. Метою функціонування системи контролю $є$ отримання позитивного результату функціонування контрольної системи. Результативність можна вважати важливим критерієм митного контролю.

На рівні державного фінансового контролю більшість науковців оперують поняттям «ефект контролю», який показує одержаний результат функціонування системи державного фінансового контролю. Зазвичай виокремлюють соціальний, організаційний та економічний ефекти. Соціальний ефект полягає у тому, що згідно з його результатами до осіб, які допустили виникнення фінансових порушень, застосовують заходи, що мають в цілому поліпшити соціальний клімат в країні, наприклад, звільнення посадових осіб та притягнення їх до відповідальності. Тобто «...фінансовий контроль виконання бюджету не дозволяє відволікати кошти, які спрямовуються на соціальні програми, на інші цілі, що забезпечують розвиток таких соціальних інститутів, як освіта, житлово-комунальне господарство, пенсійне забезпечення тощо» [12].

Організаційний ефект полягає в тому, що за результатами контрольних заходів проводяться організаційні заходи, спрямовані на покращення структури виконавчої влади, що підвищує керованість процесами використання бюджетних коштів, покращує скоординованість дій між різними ланками фінансової системи. Економічний ефект державного фінансового контролю полягає у забезпеченні повернення коштів, використаних не за цільовим призначенням, а також штрафних санкцій до державного бюджету. Це впливатиме на покращення діяльності органів влади в контексті економії бюджетних коштів. Показники для оцінки економічного ефекту функціонування системи державного фінансового контролю представлено в таблиці 1.

Таблиия 1

Показники для оцінки економічного ефекту функиіонування системи державного фінансового контролю

\begin{tabular}{|c|c|c|}
\hline $\begin{array}{l}\text { № } \\
3 / n\end{array}$ & Найменування показника & Методика розрахунку \\
\hline 1 & $\begin{array}{c}\text { Коефіціснт інтенсивності контрольної } \\
\text { роботи (Кін) }\end{array}$ & $\begin{array}{l}\text { Кiн }=N i / N, \\
\text { де } N i-\text { кількість проведених контрольних заходів одним } \\
\text { контролером; } N \text { - загальна кількість проведених контрольних } \\
\text { заходів }\end{array}$ \\
\hline 2 & $\begin{array}{l}\text { Коефіцієнт результативності } \\
\text { контрольних заходів }(K p)\end{array}$ & $\begin{array}{l}\text { Кp=(Vнu+Vuc) } / V \text {, } \\
\text { де } V н u-\text { обсяг нецільового використання коштів; Vuc - сума } \\
\text { нарахованих штрафних санкцій; } V \text { - обсяг коштів, що підлягав } \\
\text { контролю }\end{array}$ \\
\hline 3 & Коефіцієнт дієвості контролю (Кд) & 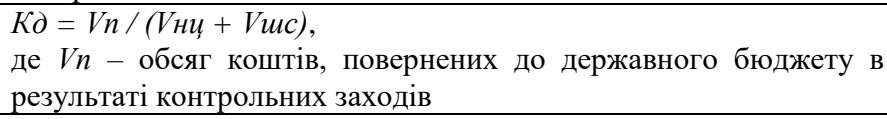 \\
\hline 4 & Коефіцієнт окупності (Ко) & $\begin{array}{l}\text { Кo }=V n / V y, \\
\text { де } V y-\text { обсяг коштів, спрямованих на утримання контролерів }\end{array}$ \\
\hline
\end{tabular}

Джерело: складено автором за [2, 3, 11, 12]

3 критерієм результативності тісно пов'язаний критерій дієвості контролю, що відображає той позитивний вплив, який контроль здійснює на утримання діяльності органу або особи, що перевіряється, iii якість, вміння контролюючого виправити положення: забезпечити своєчасне й повне виконання підконтрольним об'єктом своїх порад, рекомендацій, вказівок та пропозицій, а за необхідності досягти їх виконання, використовуючи надані законодавством повноваження [3]. Адаптуючи трактування змісту цього критерію для митного контролю, дієвість слід пов'язати зі стадією реалізації результатів контрольних заходів, яка містить аналіз того, як порушники митного законодавства сплачують нараховані штрафи та виконують інші приписи контролюючих органів. Одним 3 критеріїв, за якими також оцінюють ефективність контролю, $є$ економічність, тобто організація контрольного процесу 3 мінімальними витратами. Виговська Н.Г. стверджує, що за допомогою контролю досягається певна економічність, яка є вужчим поняттям, ніж ефективність, і передумовою для ії реалізації.

Під критерієм розуміють вимогу, що визначає правило однозначного вибору засобів досягнення мети. У більш складних випадках вирази, що пов'язують мету i засоби, називають критерієм ефективності. Якщо слід задовольнити не одну вимогу, то ці вирази отримують шляхом різноманітних об'єднань критеріїв. Представлення мети у вигляді критеріїв ефективності дозволяє вирішити питання вибору засобів для досягнення мети шляхом оптимізації їх аналітичних виразів. Вважаємо, що поняття «критерій» $є$ близьким за змістом до поняття «правила вирішення завдання», що випливає 3 конкретної сформульованої мети. За допомогою критеріїв ефективності вивчається результат внутрішніх і зовнішніх зв'язків системи. 3 цією метою вони мають бути пов'язані як із діяльністю системи контролю, так і 3 
цілями та завданнями їі об'єктів. Відповідно критерії дозволяють розкриватись якісній стороні явищ та процесів, а показники служать для кількісного вимірювання досягнутої рівності. Особливості контролю та характер його прояву показують, що через єдиний критерій не можна оцінити ефективність контролю.

Критерії надають можливість оцінити ефективність митного контролю якісно. Кількісна оцінка ефективності контролю передбачає формування системи кількісних показників, які можуть бути абсолютними та відносними. До абсолютних показників належать: ефект від функціонування системи контролю, витрати на здійснення контролю; кількість проведених перевірок тощо. До відносних можна зарахувати економічну ефективність як «...відносний показник, який дає можливість порівняти одержаний ефект із затратами чи ресурсами, що використовуються для отримання цього ефекту. Значення цього показника вже не можна сумувати в просторі та часі» [3].

Оцінюючи ефективність муніципального контролю як виду державного фінансового контролю, в економічній літературі застосовується така система показників (табл. 2).

Таблиия 2

Показники оцінки ефективності муніцуипального контролю

\begin{tabular}{|c|c|c|}
\hline $\begin{array}{l}\text { № } \\
3 / n\end{array}$ & Найменування показника & Методика розрахунку \\
\hline 1 & $\begin{array}{c}\text { Коефіцієнт } \\
\text { результативності контролю } \\
(\text { Кр) }\end{array}$ & $\begin{array}{l}\text { Кp }=(О н з+O н и+O н е) / O о, \\
\text { де Онз - обсяг незаконно використаних коштів; Онив - обсяг нецільового } \\
\text { використання; Оне - обсяг неефективного використання коштів; Оо - } \\
\text { загальний обсяг коштів, що підлягали контролю }\end{array}$ \\
\hline 2 & Коефіцієнт збитку (Кз) & $\begin{array}{l}\text { Кз } О_{3} / O б, \\
\text { де } K_{3}-\text { коефіцієнт збитку (фінансових втрат); Оз - об’єм збитку (фінансових } \\
\text { втрат) }\end{array}$ \\
\hline 3 & Коефіцієнт діяльності (Кд) & 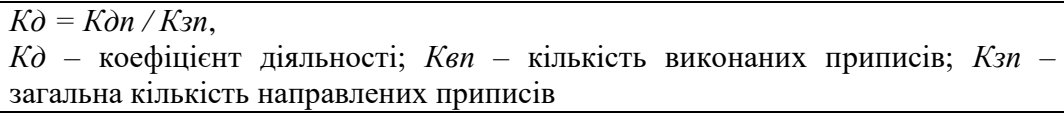 \\
\hline 4 & Коефіцієнт повернення $(K n)$ & $\begin{array}{l}\text { Kn=Oпов /On, } \\
\text { де Опов - обсяг повернених до бюджету коштів; On - обсяг коштів, } \\
\text { пред'явлених до повернення }\end{array}$ \\
\hline 5 & $\begin{array}{l}\text { Коефіцієнт економності } \\
\text { (Кек) }\end{array}$ & $\begin{array}{l}\text { Кек }=\text { Опов /Oфк, } \\
\text { де Oфк - обсяг коштів, витрачених на утримання органів фінансового } \\
\text { контролю }\end{array}$ \\
\hline 6 & $\begin{array}{c}\text { Коефіцієнт обгрунтованості } \\
\text { витрат (Коб) }\end{array}$ & $\begin{array}{l}\text { Коб }=(О н з+О н ц+\text { Оне }) / \text { Офк, } \\
\text { де Коб - коефіцієнт обгрунтованості витрат }\end{array}$ \\
\hline 7 & $\begin{array}{c}\text { Коефіцієнт } \\
\text { персонального авантаження } \\
\text { (інтенсивності) роботи } \\
(\text { Кин (iнm)) }\end{array}$ & $\begin{array}{l}\text { Кnн }(\mathrm{iнm})=\text { Ккз / Ч, } \\
\text { де Кnн (iнm)- коефіцієнт персонального навантаження (інтенсивності); Ккз - } \\
\text { кількість контрольних заходів; } 4-\text { чисельність працівників органу } \\
\text { фінансового контролю }\end{array}$ \\
\hline
\end{tabular}

Джерело: узагальнено за [2, 3, 12]

Враховуючи специфіку митного контролю та його місце у системі фінансової безпеки, закордонний досвід пропонує такий перелік оціночних індикаторів [8]: 1) граничний час проходження митних операцій під час здійснення митної процедури експорту для товарів, які не ідентифіковані як ризиковані поставки, що потребують додаткової перевірки; 2) граничний час проходження митних операцій під час здійснення митної процедури експорту для товарів внутрішнього споживання, які не ідентифіковані як ризиковані поставки, що потребують додаткової перевірки, та які не підлягають додатковим видам державного контролю; 3) частка декларацій на товари, оформлених в електронному вигляді без надання документів та відомостей на паперових носіях, в загальній кількості оформлених декларацій на товари за умови, що товари (транспортні засоби) не ідентифіковано як ризикові поставки, що вимагають додаткової перевірки документів на паперових носіях (з 40 \% у 2012 році до $100 \%$ до 2014 року); 4) частка декларацій на товари, ввезені на територію країни, митні операції і митний контроль щодо яких здійснюється в митних органах, розташованих в прикордонних суб'єктах країни, в загальному обсязі декларацій на товари; 5) кількість документів, необхідних для митних цілей під час переміщення товару через державний кордон при імпорті (експорті); 6) частка випадків недотримання обмежень, встановлених відповідно до законодавства країни, а також порушень валютного законодавства під час розміщення товарів у митні процедури; 7) результативність виконання державної функції щодо здійснення в межах своєї компетенції контролю за валютними операціями резидентів і нерезидентів, пов’язаних з переміщенням товарів через митний кордон.

До зазначених вище критеріїв В.С. Бірюкова додає індикатори, пов'язані з [4]: 1) удосконаленням фіскальної функції митних органів (рівень виконання планів по надходженню митних платежів до бюджету; частка митних платежів, повернених платникам у зв'язку із задоволенням скарг учасників 
зовнішньоекономічної діяльності на рішення або дію митного органу та його посадової особи, в загальному обсязі сплачених митних платежів (не більше 5 \% щорічно); 2) удосконаленням правоохоронної функції митних органів (кількість порушень в області митної справи; частка справ про митні порушення у загальній кількості покарань); 3) сприянням розвитку інтеграційних процесів та міжнародного співробітництва (кількість угод про співробітництво у митній справі з митними органами інших держав); 4) удосконаленням системи державних послуг (частка учасників зовнішньоекономічної діяльності, які задовільно оцінюють якість надання державних послуг митними органами у загальній кількості опитаних).

Досліджуючи ефективність митного контролю, можна погодитися з твердженням С.Г. Дем’янчука, який пише, що ефективність має оцінюватися абсолютними показниками кількості виявлених митних правопорушень за певний період роботи митниць; обсягу накладених за цей період митних штрафів за виявлені порушення, обсягу оціночної вартості затриманих об'єктів незаконних переміщень; обсягу умовної шкоди державі у зв'язку з виявленими незаконними переміщеннями певних об'єктів [5]. Уточнюючи трактування ефективності митного контролю, Н.В. Архірейська ототожнює його із ефективністю діяльності митних органів та розуміє під цим поняттям «співвідношення результатів діяльності митної справи (стягнення митних платежів, кількість оформлених митних декларацій, тощо) та залучених для досягнення таких результатів ресурсів (матеріальних, трудових)» [1]. В цілому доцільно виокремити 4 основні підходи до оцінки ефективності митного контролю в системі фінансової безпеки держави (табл. 3).

Таблиия 3

Методичні підходи до оцінювання ефективності митного контролю у системі фінансової безпеки

\begin{tabular}{|c|c|c|c|c|}
\hline $\begin{array}{l}\text { № } \\
3 / n\end{array}$ & $\begin{array}{c}\text { Назва } \\
\text { методичного } \\
\text { підходу }\end{array}$ & $\begin{array}{c}\text { Методичні підходи до оиінювання } \\
\text { ефективності }\end{array}$ & Недоліки підходу & Переваги підходу \\
\hline 1 & Порівняльний & $\begin{array}{c}\text { Ефективність як співвідношення } \\
\text { результатів діяльності митних } \\
\text { служб (послуги з митного } \\
\text { оформлення і контролю, } \\
\text { справляння податків і зборів) до } \\
\text { витрат (фонди, призначені митним } \\
\text { органам для здійснення } \\
\text { адміністративної діяльності) }\end{array}$ & $\begin{array}{c}\text { Відсутність прямого } \\
\text { зв’язку між сумами } \\
\text { митних надходжень та } \\
\text { витрат на утримання } \\
\text { митних органів; } \\
\text { нівелювання впливу } \\
\text { зовнішнього середовища } \\
\text { на суму митних платежів }\end{array}$ & $\begin{array}{l}\text { Надає можливість } \\
\text { порівняння ефекту, } \\
\text { одержаного від } \\
\text { діяльності митних } \\
\text { органів, з витратами } \\
\text { на їх утримання }\end{array}$ \\
\hline 2 & Результатний & $\begin{array}{c}\text { Ефективність як результативність } \\
\text { діяльності митних органів, що } \\
\text { визначається метою їх } \\
\text { функціонування (характеризується } \\
\text { такими показниками та критеріями: } \\
\text { обсяг перерахованих до Державного } \\
\text { бюджету митних платежів; сума } \\
\text { додаткових надходжень від } \\
\text { коригування митної вартості; } \\
\text { кількість оформлених вантажних } \\
\text { митних декларацій одним } \\
\text { працівником; час здійснення митних } \\
\text { процедур; сума недоотриманих } \\
\text { митних платежів тощо) }\end{array}$ & $\begin{array}{c}\text { Мета діяльності митних } \\
\text { органів деталізується у } \\
\text { низці завдань, які часто є } \\
\text { різноспрямованими, що } \\
\text { не дає можливості } \\
\text { односпрямовано оцінити } \\
\text { ступінь її досягнення, } \\
\text { тобто ефективність }\end{array}$ & $\begin{array}{c}\text { Прямий } \\
\text { взаємозв'язок із } \\
\text { сумами митних } \\
\text { надходжень до } \\
\text { бюджету, що } \\
\text { дозволяє } \\
\text { опосередковано } \\
\text { оцінити рівень } \\
\text { фінансової безпеки }\end{array}$ \\
\hline 3 & Бенчмаркінг & $\begin{array}{c}\text { Ефективність як ступінь } \\
\text { відповідності діяльності митних } \\
\text { органів еталону }\end{array}$ & $\begin{array}{c}\text { Складність у виявленні } \\
\text { еталонного об’єкта для } \\
\text { порівняння }\end{array}$ & $\begin{array}{c}\text { Значущість для } \\
\text { аналізу ефективності } \\
\text { діяльності митних } \\
\text { органів на } \\
\text { регіональному рівні } \\
\end{array}$ \\
\hline 4 & $\begin{array}{c}\text { Клієнто- } \\
\text { орієнтований } \\
\text { підхід }\end{array}$ & $\begin{array}{c}\text { Ефективність як ступінь } \\
\text { задоволеності користувачів митних } \\
\text { послуг діяльністю митних органів } \\
\text { (пасажиропотік, час проведення } \\
\text { митних процедур, навантаження на } \\
\text { одного працівника митних органів; } \\
\text { час на виконання митних процедур } \\
\text { в автомобільних пунктах пропуску; } \\
\text { питома вага електронних митних } \\
\text { декларацій у загальній кількості } \\
\text { оформлених; питома вага учасників } \\
\text { ЗЕД, що позитивно оцінюють } \\
\text { роботу митних органів тощо) }\end{array}$ & $\begin{array}{c}\text { Різноспрямованість } \\
\text { інтересів суб'єктів, } \\
\text { зацікавлених в успішному } \\
\text { функціонуванні митних } \\
\text { органів }\end{array}$ & $\begin{array}{c}\text { Орієнтація на } \\
\text { інтереси } \\
\text { зацікавлених } \\
\text { стейкхолдерів у } \\
\text { функціонуванні } \\
\text { митних органів }\end{array}$ \\
\hline
\end{tabular}


Оцінка переваг та недоліків існуючих підходів до ефективності митного контролю дає можливість запропонувати науково-методичний підхід, який поєднує бенчмаркінг результатів та клієнтоорієнтований підхід. Бенчмаркінг є одним 3 аналітичних інструментів еталонного тестування, а також вирішення проблем неефективного функціонування окремих суб'єктів. Узагальнення існуючих підходів дозволило визначити бенчмаркінг як систематичний процес порівняльного аналізу та оцінювання методів і результатів діяльності підприємства, його структурних підходів, функцій, процесів, продуктів праці тощо через зіставлення з обраними еталонами чи орієнтирами, до яких воно прагне або бажає покращитися у стратегічній перспективі [6].

Існує значна кількість класифікаційних ознак бенчмаркінгу, однак у контексті нашої предметної області основою запропонованого науково-методичного підходу буде бенчмаркінг результатів, який полягає у порівнянні отриманих результатних аналітичних показників 3 подальшим вивченням процесів, завдяки яким досягнуто їхніх оптимальних значень. Такий науково-методичний підхід доповнимо елементами клієнтоорієнтованого підходу, за якого ефективність розглядається як ступінь задоволеності користувачів митних послуг діяльністю митних органів. Обгрунтувати доцільність використання клієнтоорієнтованого підходу можна таким чином: 1) механізм контролю спрямований не лише на оцінку результатів, але й на оцінку якості послуг, що надаються митними органами (зокрема, регіональними митницями); 2) специфіка митних послуг, що надаються споживачам, полягає у їх колективному користуванні (суспільне благо), критерії якості якого визначити складно; 3) якість послуг може оцінюватися шляхом опитування споживачів щодо якості кадрового, організаційного забезпечення діяльності митниць.

Спільне використання бенчмаркінгу результатів та клієнтоорієнтованого підходу дозволить визначити ефективність діяльності митних органів з позиції збільшення митних надходжень до бюджету, підсумковий рейтинг митниць та їх порівняння з еталонним об'єктом і визначити ступінь задоволеності користувачів митних послуг діяльністю митних органів. У межах запропонованих підходів визначимо такі показники (табл. 4).

Таблиия 4

Показники оиінки ефективності митного контролю в контексті запропонованого науково-методичного підходу

\begin{tabular}{|c|c|c|}
\hline $\begin{array}{l}\text { № } \\
3 / n\end{array}$ & Назва & Показники очінки ефективності митного контролю \\
\hline 1 & Бенчмаркінг результатів & $\begin{array}{l}\text { Стандартизовані показники для аналізу суми митних платежів (суми акцизного } \\
\text { збору (X1); суми ПДВ (X2); суми мита (X3); суми надходжень від імпорту (X4) } \\
\text { та визначення інтегрального показника оцінки ефективності діяльності } \\
\text { регіональних митниць. Подальший порівняльний аналіз на підставі визначення } \\
\text { показників, виявлення та співставлення з еталонним об'єктом }\end{array}$ \\
\hline 2 & $\begin{array}{c}\text { Клієнтоорієнтований } \\
\text { підхід }\end{array}$ & $\begin{array}{l}\text { Кількість скарг; кількість задоволених скарг; \% задоволених скарг; \% задоволених } \\
\text { скарг у розрізі окремих скарг (\% задоволених скарг щодо роботи працівників } \\
\text { митниці в цілому; \% задоволених скарг щодо визначення митної вартості товару; } \\
\text { \% задоволених скарг щодо роз’яснення митного законодавства тощо) }\end{array}$ \\
\hline
\end{tabular}

Джерело: запропоновано автором

Для формування переліку показників з метою застосування бенчмаркінгу результатів виокремимо такі показники діяльності регіональних митниць: 1) суми акцизного збору (X1); 2) суми ПДВ (X2); 3) суми мита (X3); 4) суми надходжень від імпорту (X4).

Розрахунок інтегрального (рейтингового) показника будемо проводити за допомогою застосування матричної моделі. Як метод рейтингового оцінювання обрано метод Евклідової відстані. Сутність цього методу полягає в тому, що кожна регіональна митниця розглядається як окрема точка в $n$-мірному Евклідовому просторі, а відповідно координати точки - величини показників, за якими здійснюється порівняння. За допомогою методу відстаней можливо визначити відстань від еталонного об'єкта до фактичних значень показників діяльності митниць, що підлягають аналізу. Під час використання обраного методу слід взяти до уваги те, що мінімальна величина одержаної оцінки відповідає рівню найвищого рейтингу, оскільки ії відстань до еталонного значення є мінімальною.

Запропонований науково-методичний підхід до оцінки ефективності системи митного контролю із використанням методу Евклідової відстані містить такі основні етапи: 1) формування показників діяльності регіональних митниць за 2017-2019 роки; 2) складання матриці стандартизованих показників для аналізу суми митних платежів за 2017-2019 роки, що розраховуються діленням кожного фактичного показника діяльності митниці на еталонний коефіцієнт. Обрані еталонні показники складають одиницю; 3) складання нової матриці, яка містить величини розрахованих відстаней для кожної регіональної митниці до еталонної митниці. Розраховані значення відстаней підсумовуються; 4) ранжування митниць 
у напрямі зменшення отриманої рейтингової оцінки. Це означатиме, що найвищий рівень рейтингової оцінки матиме митниця з мінімальним одержаним значенням Евклідової відстані. Під час використання методики Евклідової відстані слід враховувати необхідність односпрямованості показників, що здійснюється шляхом застосуванням методики нормалізації, яка різниться для показників-стимуляторів (показників, які позитивно впливають в контексті нашого дослідження на рівень фінансової безпеки) та показників-дестимуляторів (які мають зворотній вплив).

Всі початкові аналітичні показники є стимуляторами, оскільки їх зростання сприятиме зростанню суми доходів державного бюджету, що підвищує рівень фінансової безпеки держави. Таким чином, для нормалізації початкових даних вихідної матриці застосовується формула:

$$
Z i j=X i j / \max X i j \text {, }
$$

де $X i j$ - нормалізоване значення $i$-го показника матриці для $j$-го періоду;

$\max X i j$ - еталонне значення показника.

Формула для кінцевого розрахунку рейтингової оцінки $(R) \in$ такою:

$$
R=\left[(1-Z 1 j)^{2}+(1-Z 2 j)^{2}+\ldots(1-Z n j)^{2}\right]^{1 / 2},
$$

де $R$ - рейтингова оцінка, що характеризує ефективність діяльності регіональної митниці.

За результатами використання цієї методики зведено рейтингову оцінку ефективності діяльності регіональних митниць за визначеними показниками митних надходжень у 2017-2019 роках (табл. 5).

Рейтингова очінка ефективності діяльності митниць за 2017-2019 роки

Таблиия 5

\begin{tabular}{|c|c|c|c|c|c|c|c|c|}
\hline \multirow{2}{*}{ Митниияя } & \multicolumn{2}{|c|}{2017} & \multicolumn{2}{|c|}{2018} & \multicolumn{2}{|c|}{2019} & \multirow{2}{*}{$\begin{array}{l}\text { Показник } \\
\text { середньої } \\
\text { рейтинго- } \\
\text { вої оцінки }\end{array}$} & \multirow{2}{*}{$\begin{array}{c}\text { Місие y } \\
\text { рейтингу }\end{array}$} \\
\hline & Показник & Рейтинг & Показник & Рейтинг & Показник & Рейтинг & & \\
\hline $\begin{array}{l}\text { Азовська } \\
\text { митниця }\end{array}$ & 8 & 10 & 1,919708 & 9 & 1,935954 & 14 & 11 & 11 \\
\hline $\begin{array}{l}\text { Буковинсь- } \\
\text { ка митниця }\end{array}$ & 1,95 & 14 & 1,965023 & 14 & 1,926459 & 13 & 13,6 & 13 \\
\hline $\begin{array}{c}\text { Волинська } \\
\text { митниця }\end{array}$ & 1,88 & 8 & 1,856274 & 7 & 1,818456 & 7 & 7,33 & 7 \\
\hline $\begin{array}{c}\text { Галицька } \\
\text { митниця } \\
\end{array}$ & 1,74 & 5 & 1,727208 & 5 & 1,659441 & 5 & 5,0 & 5 \\
\hline $\begin{array}{l}\text { Дніпровсь- } \\
\text { ка митниця }\end{array}$ & 1,62 & 3 & 1,60453 & 4 & 1,645764 & 4 & 3,66 & 4 \\
\hline $\begin{array}{l}\text { Енергетич- } \\
\text { на митниця }\end{array}$ & 1,06 & 2 & 1,04286 & 2 & 1,0848 & 2 & 2,0 & 2 \\
\hline $\begin{array}{l}\text { Закарпатсь- } \\
\text { ка митниця }\end{array}$ & 1,94 & 13 & 1,927641 & 11 & 1,895167 & 8 & 10,66 & 10 \\
\hline $\begin{array}{l}\text { Київська } \\
\text { митниця }\end{array}$ & 0,94 & $1 *$ & 0,959943 & $1^{*}$ & 0,944474 & $1 *$ & 1,0 & $1^{*}$ \\
\hline $\begin{array}{l}\text { Одеська } \\
\text { митниця }\end{array}$ & 1,68 & 4 & 1,57674 & 3 & 1,461995 & 3 & 3,33 & 3 \\
\hline $\begin{array}{l}\text { Північна } \\
\text { митниця }\end{array}$ & 1,85 & 7 & 1,89198 & 8 & 1,919013 & 12 & 9,0 & 8 \\
\hline $\begin{array}{c}\text { Подільська } \\
\text { митниця }\end{array}$ & 1,93 & 11 & 1,932317 & 13 & 1,90701 & 10 & 11,33 & 12 \\
\hline $\begin{array}{c}\text { Поліська } \\
\text { митниця } \\
\end{array}$ & 1,91 & 9 & 1,927061 & 10 & 1,906558 & 9 & 9,33 & 9 \\
\hline $\begin{array}{c}\text { Слобо- } \\
\text { жанська } \\
\text { митниця }\end{array}$ & 1,79 & 6 & 1,808169 & 6 & 1,812558 & 6 & 6,0 & 6 \\
\hline $\begin{array}{c}\text { Східна } \\
\text { митниця } \\
\end{array}$ & $1,99 * *$ & $15^{* *}$ & $1,990365 * *$ & $15 * *$ & $1,992911 * *$ & $15 * *$ & 15,0 & $14 * *$ \\
\hline $\begin{array}{c}\text { Чорно- } \\
\text { морська } \\
\text { митниця }\end{array}$ & 1,93 & 12 & 1,929584 & 12 & 1,918826 & 11 & 11,66 & 12 \\
\hline
\end{tabular}
(на основі розрахунку інтегрального показника митних надходжень)

На підставі аналізу даних таблиці 5 можна зробити висновок, що рейтингування підприємств здійснювалося у порядку зменшення отриманих показників. Найвищий рейтинг у 2017-2019 роках мала 
Київська регіональна митниця, показники якої змінювалися у діапазоні [0,94-0,959]. Це дає підстави вважати iї еталонною 3 позиції отримання найвищих результативних показників (акумулювання надходжень до бюджету) (рис. 1). Найгірші показники порівняно з еталонним об'єктом у Східної митниці, які варіюють у діапазоні [1,99-1,992911]. Одержані результати підтверджено результатами розпочатого кримінального впровадження за фактами, виявленими працівниками СБУ у 2020 році. СБУ блокувала функціонування вертикально побудованої корупційної схеми, організованої керівництвом Східної митниці ДФС України. Правоохоронці отримали докази систематичного вимагання митниками грошей від комерсантів за проведення митного оформлення товарних партій у режимі імпорт та встановили, що корупційна схема дозволяла керівництву Східної митниці тривалий час отримувати неправомірну вигоду у розмірі понад 5 млн грн на рік, що підтверджує ненадходження цих коштів до державного бюджету України [9].

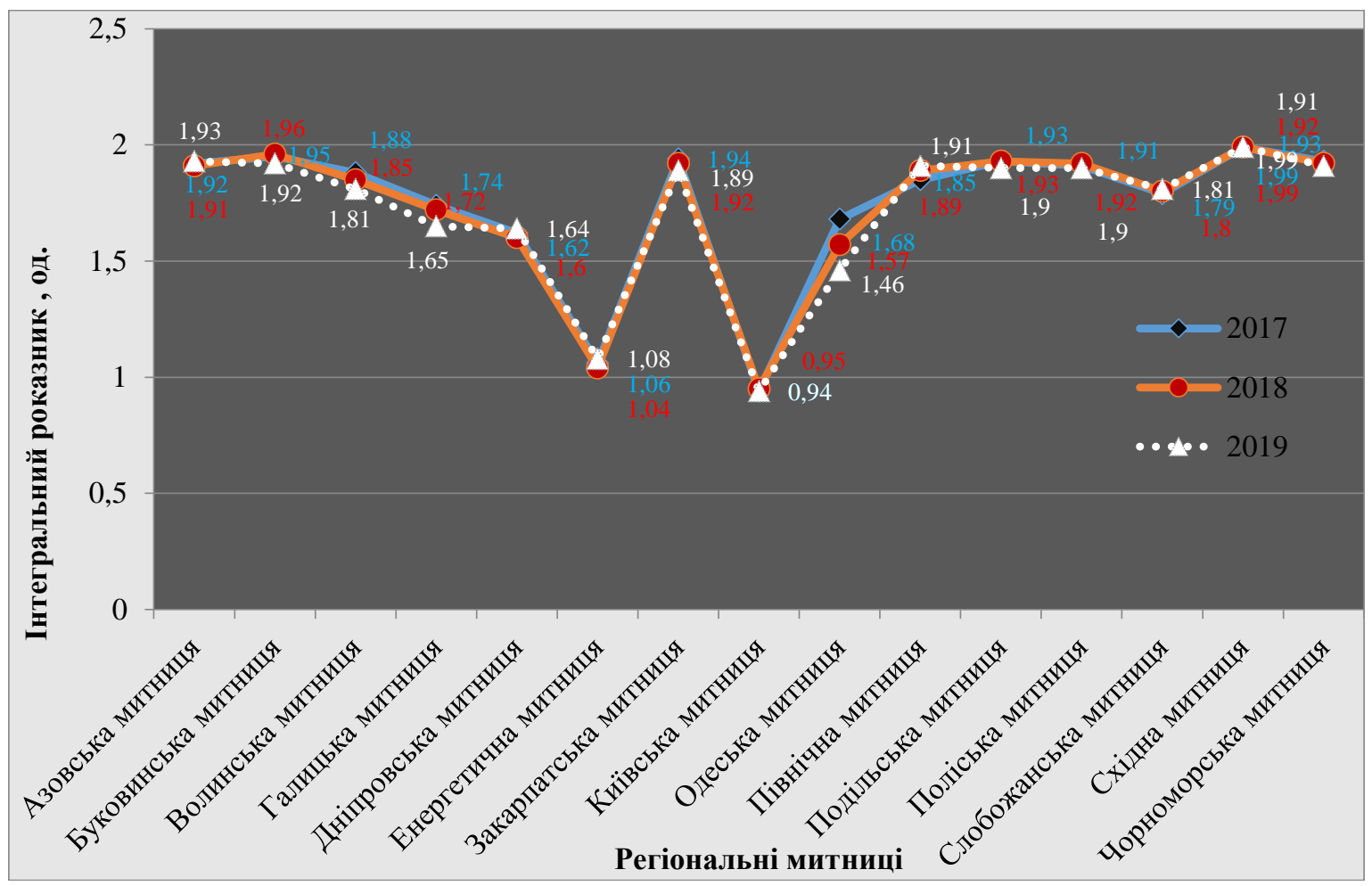

Рис. 1. Рейтингова оцінка ефективності діяльності митниць за 2017-2019 роки (на основі розрахунку інтегрального показника митних надходжень)

Застосовуючи клієнтоорієнтований підхід для визначення ефективності діяльності регіональних митниць, основними критеріями обрано:

1) \% задоволених скарг;

2) \% задоволених скарг у розрізі:

- \% задоволених скарг щодо роботи працівників митниці в цілому;

- $\quad$ \% задоволених скарг щодо визначення митної вартості товару;

- \% задоволених скарг щодо роз'яснення митного законодавства тощо.

Методичним забезпеченням використання клієнтоорієнтованого підходу для визначення ефективності діяльності регіональних митниць використано метод «суми місць». Запропонований метод побудовано на здійсненні попереднього ранжування всіх досліджуваних структурних об'єктів (у цьому випадку регіональних митниць) за окремими показниками чи критеріями. Кожному об’єкту (регіональній митниці) відповідає значення $i$-го показника $X i j$, яке виражає його місце серед інших. Зазвичай при цьому використовують зважування значущості кожного показника $X i j$ за допомогою вибору вагових коефіцієнтів та формують таблицю за показниками. В підсумку відбувається розрахунок рейтингової оцінки за формулою:

$$
K i=S X i j \times b i j \text {. }
$$

У випадку визначення ефективності митного контролю вважаємо недоцільним застосовувати коефіцієнти вагомості для ранжування значущості обраних критеріїв, оскільки відсоток задоволених скарг у розрізі різних питань діяльності митниці є рівнозначно значущим критерієм для визначення рейтингової оцінки. Таким чином, маємо такі результати (табл. 6). 
Таблиия 6

Показники ефективності роботи регіональних митниць відповідно до клієнтоорієнтованого підходу

\begin{tabular}{|c|c|c|c|c|c|c|c|c|c|c|c|c|}
\hline 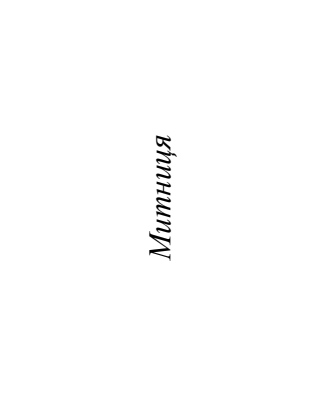 & 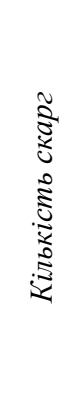 & 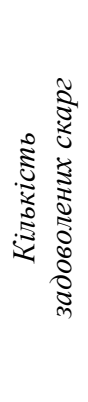 & 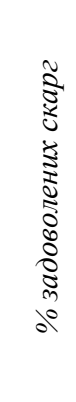 & 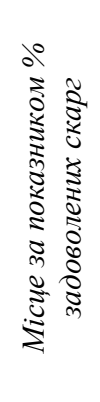 & 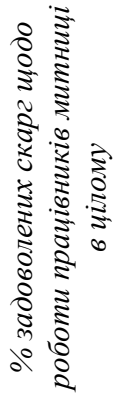 & 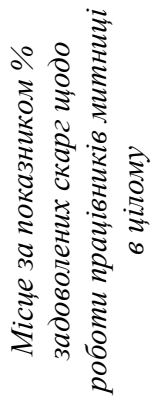 & 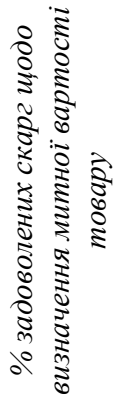 & 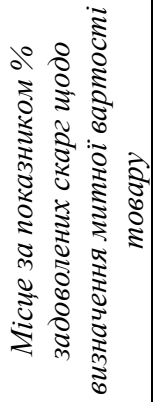 & 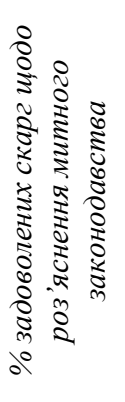 & 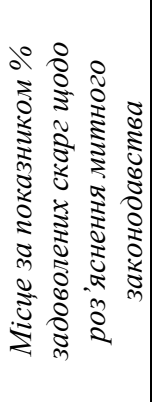 & 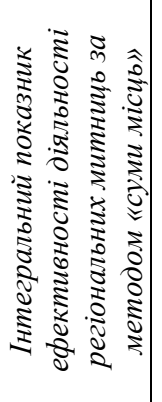 & 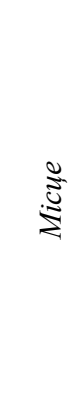 \\
\hline Одеська митниця & 460 & 405 & 88,0 & $1 *$ & 68,3 & 7 & 47,6 & 7 & 100,0 & 1 & 16 & 5 \\
\hline Київська митниця & 751 & 195 & 26,0 & 6 & 65,0 & 10 & 73,3 & 3 & 87,0 & 5 & 24 & 8 \\
\hline Волинська митниця & 188 & 131 & 69,0 & 2 & 68,0 & 8 & 100,0 & 1 & 92,9 & 2 & 13 & 3 \\
\hline Дніпровська митниця & 175 & 110 & 63,0 & 3 & 80,0 & 4 & 75,0 & 2 & 100,0 & 1 & 10 & $1 *$ \\
\hline Галицька митниця & 588 & 74 & 12,5 & 12 & 76,0 & 5 & 61,1 & 5 & 92,0 & 3 & 25 & 9 \\
\hline $\begin{array}{c}\text { Закарпатська } \\
\text { митниця }\end{array}$ & 151 & 46 & 30,0 & 4 & 90,0 & 2 & 66,7 & 4 & 100,0 & 1 & 11 & 2 \\
\hline $\begin{array}{c}\text { Слобожанська } \\
\text { митниця }\end{array}$ & 182 & 37 & 20,3 & 8 & 47,4 & 12 & 33,3 & 8 & 100,0 & 1 & 29 & 11 \\
\hline Північна митниця & 132 & 26 & 19,6 & 9 & 89,5 & 3 & 50,0 & 6 & 88,9 & 4 & 22 & 7 \\
\hline Поліська митниця & 52 & 14 & 27,0 & 5 & 100,0 & 1 & 0 & 8 & 100,0 & 1 & 15 & 4 \\
\hline $\begin{array}{c}\text { Чорноморська } \\
\text { митниця }\end{array}$ & 72 & 12 & 16,6 & 11 & 66,7 & 9 & 0 & 8 & 85,7 & 6 & 34 & 13 \\
\hline Подільська митниця & 44 & 8 & 18,0 & 10 & 60,0 & 11 & 0 & 8 & 100,0 & 1 & 30 & 12 \\
\hline Буковинська митниця & 55 & 4 & 7,2 & $13 * *$ & 75,0 & 6 & 100,0 & 1 & 100,0 & 1 & 21 & 6 \\
\hline Азовська митниця & 14 & 3 & 21,4 & 7 & 0 & $13 * *$ & 0 & 8 & 100,0 & 1 & 29 & 11 \\
\hline Енергетична митниця & 6 & 1 & 16,6 & 11 & 0 & $13 * *$ & 0 & 8 & - & 7 & 39 & $14 * *$ \\
\hline Східна митниця & 13 & - & - & $13 * *$ & 0 & $13^{* * *}$ & 100,0 & 1 & 100,0 & 1 & 28 & 10 \\
\hline
\end{tabular}


Поєднання отриманих результатів рейтингової оцінки на основі використання результатного бенчмаркінгу та клієнтоорієнтованого підходу дає можливість розрахувати інтегральний показник ефективності діяльності регіональних митниць та за допомогою методу «суми місць» ранжувати одержані оцінки, визначивши місце кожної митниці в одержаному кінцевому рейтингу (табл. 7).

Таблиия 7

Інтегральний показник ефективності діяльності регіональних митниць на підставі поєднання результатного бенчмаркінгу та клієнтоорієнтованого підходу

\begin{tabular}{|c|c|c|c|c|}
\hline Митниця & $\begin{array}{c}\text { Показник } \\
\text { середньої } \\
\text { рейтингової } \\
\text { оцінки (на основі } \\
\text { використання } \\
\text { результатного } \\
\text { бенчмаркінгу) }\end{array}$ & $\begin{array}{c}\text { Показник } \\
\text { рейтингової } \\
\text { оцінки (на основі } \\
\text { використання } \\
\text { клієнто- } \\
\text { орієнтованого } \\
\text { підходу) }\end{array}$ & $\begin{array}{c}\text { Інтегральний показник } \\
\text { ефективності } \\
\text { діяльності регіональних } \\
\text { митниць на підставі } \\
\text { поєднання результат- } \\
\text { ного бенчмаркінгу та } \\
\text { клієнтоорієнтованого } \\
\text { підходу }\end{array}$ & $\begin{array}{c}\text { Місие, } \\
\text { отримане за } \\
\text { результатом } \\
\text { визначення } \\
\text { інтегрального } \\
\text { показника }\end{array}$ \\
\hline Азовська митниця & 11 & 11 & 11,0 & 12 \\
\hline Буковинська митниця & 13 & 6 & 9,5 & 11 \\
\hline Волинська митниця & 7 & 3 & 5,0 & 4 \\
\hline Галицька митниця & 5 & 9 & 7,0 & 7 \\
\hline Дніпровська митниця & 4 & 1 & 2,5 & $1 *$ \\
\hline Енергетична митниця & 2 & 14 & 8,0 & 9 \\
\hline Закарпатська митниця & 10 & 2 & 6,0 & 5 \\
\hline Київська митниця & 1 & 8 & 4,5 & 3 \\
\hline Одеська митниця & 3 & 5 & 4,0 & 2 \\
\hline Північна митниця & 8 & 7 & 7,5 & 8 \\
\hline Подільська митниця & 12 & 12 & 12,0 & 13 \\
\hline Поліська митниця & 9 & 4 & 6,5 & 6 \\
\hline Слобожанська митниця & 6 & 11 & 8,5 & 10 \\
\hline Східна митниця & 14 & 10 & 12,0 & 14 \\
\hline Чорноморська митниця & 12 & 13 & 12,5 & $15 * *$ \\
\hline
\end{tabular}

Примітка: * найкраще значення показника

** найгірше значення показника

Оцінка даних таблиці 7 дає можливість визначити, що найкраще значення інтегрального показника $\mathrm{i}$ відповідне найвище місце у рейтингу належить Дніпровській митниці, найгірше - Чорноморській. Дніпровська регіональна митниця має найвищий рейтинг 3 огляду на використання клієнтоорієнтованого підходу - це свідчить про націленість діяльності митниці на надання якісних послуг споживачам, що поєднується з достатньо високими показниками надходжень до державного бюджету митних платежів.

Запропоновано використовувати такі граничні межі для визначення рівня інтегрального показника ефективності діяльності митниці (табл. 8).

Таблиия 8

Ідентифікація рівня ефективності діяльності функціональних митниць на підставі розрахованого інтегрального показника

\begin{tabular}{|c|c|c|c|}
\hline $\begin{array}{c}\text { № } \\
3 / n\end{array}$ & $\begin{array}{c}\text { Місие, отримане за результатом } \\
\text { визначення інтегрального } \\
\text { показника ефективності } \\
\text { дільності регіональної митниці }\end{array}$ & Назва регіональної митниці & $\begin{array}{c}\text { Рівень ефективності } \\
\text { діяльності регіональної } \\
\text { митниці та необхідність } \\
\text { иого підвищення }\end{array}$ \\
\hline 1 & $0-5$ & $\begin{array}{c}\text { Дніпровська, Волинська, Одеська, } \\
\text { Київська, Закарпатська митниці }\end{array}$ & Високий \\
\hline 2 & $6-10$ & $\begin{array}{c}\text { Галицька, Північна, Поліська, } \\
\text { Слобожанська, Енергетична митниці }\end{array}$ & Середній \\
\hline 3 & $11-15$ & $\begin{array}{c}\text { Азовська, Буковинська, Подільська, } \\
\text { Східна, Чорноморська митниці }\end{array}$ & Низький \\
\hline
\end{tabular}

Джерело: власна розробка 
За умови одержання регіональною митницею високого рівня ефективності митного контролю завдання іiі подальшого функціонування - продовжувати підвищувати результативність діяльності митних органів, що визначається як мета їх функціонування, та збільшувати показники перерахованих митних платежів до бюджету. Крім того, цей рівень свідчить про високу якість митних послуг, обслуговування клієнтів, дотримання організаційної культури. Середній рівень ефективності митного контролю свідчить про наявність резервів удосконалення функціонування митних органів, що дозволить збільшити економічний ефект (суму митних надходжень), тим самим сприяючи забезпеченню відповідного рівня фінансової безпеки держави. Регіональним митницям на цьому рівні слід звернути увагу на корпоративну культуру, зменшення кількості скарг на їх роботу споживачами митних послуг, своєчасне усунення виявлених недоліків за результатами розглянутих скарг, що відповідатиме реалізації клієнтоорієнтованого підходу. Отримання низького рівня ефективності митного контролю свідчить про повну невідповідність діяльності регіональних митниць сучасним вимогам розвитку державної служби, що пріоритетом свого функціонування визнає не лише досягнення економічного, але і соціального ефекту. Це вимагає реалізації відповідних кадрових, організаційних та інших адміністративних заходів.

Висновки та перспективи подальших наукових досліджень. Таким чином, оцінка переваг та недоліків існуючих методичних підходів до аналізу ефективності митного контролю дає можливість обрати науково-методичний підхід, який $є$ поєднанням підходу, орієнтованого на бенчмаркінг результатів із застосуванням методу Евклідової відстані, та клієнтоорієнтованого підходу, результатом використання якого є визначення інтегрального показника ефективності діяльності регіональних митниць та ідентифікація місця кожної митниці у одержаному кінцевому рейтингу шляхом проведеного ранжування 3 використанням методики «суми місць». Прикладне застосування запропонованого науково-методичного підходу дозволить визначити ефективність діяльності митних органів 3 позиції збільшення митних надходжень до бюджету та забезпечення відповідного рівня фінансової безпеки, встановити ступінь задоволеності користувачів митних послуг діяльністю митних органів.

В цілому, віддаючи належну увагу методам багатовимірних порівнянь, аналітики разом 3 тим зазначають, що розраховуючи показник комплексної (інтегральної) оцінки треба пам'ятати про те, що він $\epsilon$ лише операційним поняттям і не має самостійного економічного змісту. Тому він має право на існування лише у практиці порівняльного аналізу з метою ранжування об'єктів і прийняття рішень. Недоліками методів багатовимірних порівнянь $\epsilon$ складність у розрахунках, недостатня наочність і суперечливість, оскільки величини з більшою варіацією матимуть вищу вагу в інтегральному показнику, завдяки чому вони отримують перевагу порівняно з іншими показниками.

Список використаної літератури:

1. Архірейська Н.В. Аналіз підходів до оцінювання ефективності митної справи / Н.В. Архірейська // Ефективна економіка. - 2014. - № 7 [Електронний ресурс]. - Режим доступу : http://www.economy.nayka.com.ua/?op=1\&z=3176.

2. Бардаш С.В. Економічний контроль в Україні: системний підхід : монографія / С.В. Бардаш. - К. : КНТЕУ, 2010. $-656 \mathrm{c}$.

3. Виговська Н.Г. Господарський контроль в Україні: теорія, методологія, організація : монографія / Н.Г. Виговська. - Житомир : ЖДТУ, 2008. - 532 с.

4. Бирюкова B.E. Система целевых индикаторов развития таможенной службы РФ и разработка предложений по ее совершенствованию / B.E. Бирюкова [Электронный ресурс]. - Режим доступа : https://novaum.ru/public/p1535.

5. Дем'янчук С.Г. Аналітико-статистичні моделі для прогнозування та підвищення ефективності функціонування систем митного контролю : автореф. дис. на здобуття наук ступ. к.т.н. : спец. $05.13 .06 /$ С.Г. Дем'янчук. - Київ : Нац. транспорт. ун-т, 2005. - 19 с.

6. Дубодєлова А.В. Особливості та технологія внутрішнього бенчмаркінгу на підприємстві / А.В. Дубодєлова, О.В. Юринещь // Маркетинг і менеджмент інновацій. - 2013. - № 2. - С. 64-73.

7. Липатова Н.Г. Имитационное моделирование процессов таможенного контроля : монография / Н.Г. Липатова. - М. : Изд-во Российской таможенной академии, 2015. - 164 с.

8. О Стратегии развития таможенной службы Российской Федерации до 2020 года : Распоряжение Правительства РФ от 28.12.2012 № 2575-р : ред. от 10.02.2018 [Электронный ресурс]. - Режим доступа : https://customs.gov.ru/activity/programmy-razvitiya/strategy.

9. СБУ викрила керівництво Східної митниці на організації корупційної схеми на понад 5 мільйонів гривень [Електронний ресурс]. - Режим доступу : https://ssu.gov.ua/novyny/sbu-vykryla-kerivnytstvo-skhidnoimytnytsi-na-orhanizatsii-koruptsiinoi-skhemy-na-ponad-5-milioniv-hryven.

10. Словник української мови : в 11 томах. - 1977. - Т. 8.

11. Шевченко Н.В. Механізм оцінки ефективності державного фінансового контролю в Україні : автореф. дис. на здобуття наук. ступеня к.е.н. : спец. 08.00.08 / Н.В. Шевченко. - Суми : СумДУ, 2011. - 21 с.

12. Государственный финансовый контроль / С.О. Шохин, Н.С. Столяров, В.А. Жуков, С.В. Степашин. Москва : Рид Групп, 2012. 


\section{References:}

1. Arhirejs'ka, N.V. (2014), «Analiz pidhodiv do ocinjuvannja efektyvnosti mytnoi' spravy», Efektyvna ekonomika, No. 7, [Online], available at: http://shshsh.economy.nayka.com.ua/?op=1\&z=3176

2. Bardash, S.V. (2010), Ekonomichnyj kontrol' v Ukrai'ni: systemnyj pidhid, monografija, KNTEU, K., 656 p.

3. Vygovs'ka, N.G. (2008), Gospodars'kyj kontrol' v Ukrai'ni: teorija, metodologija, organizacija, monografija, ZhDTU, Zhytomyr, $532 \mathrm{p}$.

4. Biryukova, V.E., «Sistema tselevykh indikatorov razvitiya tamozhennoi sluzhby RF i razrabotka predlozhenii po ee sovershenstvovaniyu», [Online], available at: https://novaum.ru/public/p1535

5. Dem'janchuk, S.G. (2005), «Analityko-statystychni modeli dlja prognozuvannja ta pidvyshhennja efektyvnosti funkcionuvannja system mytnogo kontrolju», Abstract of Ph.D. dissertation, spec. 05.13.06, Nac. transport. un-t, Kyi'v, 19 p.

6. Dubodjelova, A.V. and Jurynec', O.V. (2013), «Osoblyvosti ta tehnologija vnutrishn'ogo benchmarkingu na pidpryjemstvi», Marketyng i menedzhment innovacij, No. 2, pp. 64-73.

7. Lipatova, N.G. (2015), Imitatsionnoe modelirovanie protsessov tamozhennogo kontrolya, monografiya, Izd-vo Rossiiskoi tamozhennoi akademii, M., 164 p.

8. Pravitel'stvo RF (2018), O Strategii razvitiya tamozhennoi sluzhby Rossiiskoi Federatsii do 2020 goda, Rasporyazhenie ot 28.12.2012, No. 2575-r, red. ot 10.02.2018, [Online], available at: https://customs.gov.ru/activity/programmy-razvitiya/strategy

9. «SBU vykryla kerivnyctvo Shidnoi' mytnyci na organizacii' korupcijnoi' shemy na ponad 5 mil'joniv gryven'», [Online], available at: https://ssu.gov.ua/novyny/sbu-vykryla-kerivnytstvo-skhidnoi-mytnytsi-na-orhanizatsiikoruptsiinoi-skhemy-na-ponad-5-milioniv-hryven

10. Slovnyk ukrai'ns'koi' movy (1977), in 11 volumes, Vol. 8.

11. Shevchenko, N.V. (2011), «Mehanizm ocinky efektyvnosti derzhavnogo finansovogo kontrolju v Ukrai'ni», Abstract of Ph.D. dissertation, spec. 08.00.08, SumDU, Sumy, 21 p.

12. Shokhin, S.O., Stolyarov, N.S., Zhukov, V.A. and Stepashin, S.V. (2012), Gosudarstvennyi finansovyi kontrol', Rid Grupp, Moskva.

Костишин Юрій Сергійович - аспірант кафедри фінансів і кредиту Державного університету «Житомирська політехніка».

https://orcid.org/0000-0003-2881-0817.

Наукові інтереси:

- фінансова безпека;

- митний контроль. 